\title{
Developments In Exchange Of Information In Tax Matters Within SADC: A Move Towards Tackling Tax Fraud In Southern Africa
}

Puseletso Letete, University of South Africa, South Africa

\begin{abstract}
In recent years around the world, it is apparent that the need for mutual assistance between states is increasing and gaining support. The Organisation for Economic Cooperation and Development (OECD) has been in the lead of this effort. This approach has also been prevalent in Africa, particularly in the Southern African Development Community (SADC) which is viewed in the context of strengthening economic integration and cooperation in the region. Recently, there has been extensive commitment by many jurisdictions around the world to eradicate problems to the exchange of information in tax matters by approving and supporting the international standard on transparency and exchange of information. The regional organisations in Sub-Saharan Africa have engaged in new trends in tax policy and administration. This has seen the adoption of agreements to regulate exchange of information in tax matters which is the subject of the present enquiry.
\end{abstract}

Keywords: SADC; Tax Policy; Information Exchange Regulations

\section{INTRODUCTION}

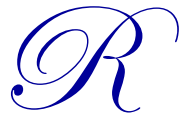

ecently most African governments have shown increasing support for regional integration and they have regarded it as an important part of their development policies and plans (Hartzenberg, 2011). In this context, regional integration is seen as an important aspect of "economic development and economic integration for developing countries in the global economy" (Letete, 2012). As a result of the growth of regional integration and increasing globalisation, member countries to regional organisations and trading blocs, are under pressure to strengthen their economic integration and their tax administration (this principle is incorporated in the VAT agreement between South Africa and Lesotho on mutual assistance and co-operation and the prevention of fiscal evasion with respect to value-added tax, available at www.sars.gov.za).

The developments over the last few years, have shown that "with taxpayers operating on a global basis, the problem of tax fraud has also increased globally" (Seer, 2013). In order to tackle this problem, tax authorities have reviewed their traditional approach which was focused on bilateral cooperation to a more inclusive approach of a wider community of states in the form of multilateral cooperation. This has also involved the shift of focus from exchange of information on request to other closer forms of cooperation, such as spontaneous exchange of information sharing (www.sars.gov.za).

This has been done as an effort to deal with international tax avoidance or cross-border tax avoidance (Pross and Russo, 2012). This is to ensure that tax laws are no longer confined to individual jurisdictions but they can have legal authority to apply in other countries in order to address the challenges which are brought about by international tax avoidance schemes. There is no doubt that international tax avoidance schemes do not have any boundaries. However, on the other hand, the issue which arises as a result of these efforts is, the relevance of the traditional approach of the principle of tax sovereignty, which recognises that the state's right to tax extends up to the border posts. It is an established principle of international tax law that, a state has the right to tax only within its sovereign borders. It seems that this new approach challenges this traditional 'tax sovereignty' principle. 
As observed by Sawyer, "following the Global Financial Crisis (hereafter GFC), the pressure from governments to collect outstanding taxes, especially those from residents' offshore bank accounts, has risen dramatically" (Sawyer, 2015. Initiatives include further efforts by the OECD to implement robust measures which are intended to achieve effective tax information amongst revenue authorities. These measures are designed to facilitate the attempts of the authorities to recover taxes which remain outstanding (Sawyer, 2015).

Recently, there has been widespread commitment by many jurisdictions around the world to abolish difficulties which hinder exchange of information in tax matters by approving "the international standard on transparency and exchange of information" (Sawyer, 2015). ${ }^{1}$ For instance, regional organisations in Sub-Saharan Africa have engaged in new trends in tax policy and tax administration. This has seen the adoption of a number of agreements in the area of tax administration particularly within the Southern African Development Community (hereafter SADC). ${ }^{2}$

SADC has made progress in developing two important documents on exchange of information and tax treaties. The SADC tax subcommittee has through the tax agreements working group developed the following documents: SADC Model Tax Agreement (2009) and SADC Agreement on Assistance in Tax Matters which was concluded in 2009 but signed in 2012. ${ }^{3}$ At the level of member countries of this regional organisation, South Africa and Lesotho; and South Africa and Swaziland have concluded agreements "on mutual assistance and co-operation and the prevention of fiscal evasion with respect to value added tax in 2015" (www.sars.gov.za).

This paper analyses the SADC Agreement on Assistance in Tax Matters as well as examining the agreements between South Africa and Lesotho; and South Africa and Swaziland as instruments for effective tax administration within the member countries. The paper examines the role of these Agreements within the context of cooperation and exchange of information in tax matters and prevention of tax fraud amongst the member countries of SADC. Furthermore, this discussion investigates the significance of these agreements within this SADC regional organisation as a means to deeper integration within the region.

The rationale behind the adoption of the SADC Agreement on Assistance in Tax Matters is to ensure that issues relating to exchange of information and tax administration in general can be dealt with more speedily amongst member states. On the other hand, the rationale behind the conclusion of the agreements between South Africa and Lesotho; and South Africa and Swaziland is to enhance the administration of value added tax (hereafter VAT) between these countries and to share exchange information which is relevant to achieving effective administration of the tax.

These SADC tax instruments will be discussed within the context of the developments in the OECD and the World at large relating to the role of agreements in exchange of information in tax issues and how they reflect a shift in tax policy and administration. This study entails a literature review of tax treaties and agreements which have been developed at the international level; the African regional level as well as the Southern African sub-regional level. The study involves a critical analysis of the design and contents of these legal instruments which underlie the exchange of information and cooperation in tax matters. It therefore reviews the move towards tax cooperation which is emerging in SADC member countries and is influenced by the developments from the OECD's multilateral initiatives. The study does not include the cost-benefit analysis of the proposed exchange of information legal regulations.

From the critical analysis of these tax instruments, it is clear that they are intended to deepen regional cooperation in tax matters within the member countries as well as with other third-party states. Therefore, tax policymakers in the concerned member countries could probably look for further approaches in this area in order to support tax administration needs of these emerging economies of SADC. This will contribute towards the development of the economies of the member countries. It is however, acknowledged that currently there is no statistics to prove that

\footnotetext{
${ }^{1}$ This has been the case within the European Union as well as in the United States. (The United States has introduced the Foreign Account Taxpayer Tax Compliance Act (FATCA) in 2010).

${ }^{2}$ SADC is a regional organisation with 15 member countries which are:- Angola, Botswana, Democratic Republic of Congo Lesotho, Madagascar, Malawi, Mauritius, Mozambique, Namibia, Seychelles, South Africa, Swaziland, Tanzania, Zambia and Zimbabwe. SADC was initially established in 1980 as SADCC (Southern African Development Coordination Conference) and it was transformed to SADC (Southern African Development Community) in 1992 (see Letete, P. 2012 at www.saflii.austlii.edu.au). For the historical background see http://www.sadc.int (accessed 6 May 2014). SADC has concluded other protocols on mutual assistance in other areas such as in criminal matters - see the Protocol on Mutual Legal Assistance in criminal matters of 2002.

${ }^{3}$ This agreement is not yet in force.
} 
deeper regional cooperation in tax matters will result in improving tax administration in these countries, and this aspect will be an issue for future research.

\section{THE RISE IN TAX COOPERATION EFFORTS}

International cooperation is the new standard in dealing with matters of "exchange of information and fiscal transparency" (Sawyer, 2014). According to Sawyer 2015, "global initiatives to combat cross-border tax avoidance and evasion has focussed upon ways in which revenue authorities can gather, and in some cases share, information to assist them in ascertaining whether their residents are engaged in unacceptable tax practices". There is a need for legal instruments to be concluded in order to engage in exchange of information. The OECD model sets the benchmark for international cooperation whereas the OECD's Multilateral Convention and the 2010 Protocol are significant developments in the areas of information exchange. There has been extensive research on the subject of greater cooperation in taxation across borders and this research acknowledges such contributions (Seer, 2013; Cavelti, 2013; Walpole, 2014; OECD, 2006). A major development in this area is marked by the move towards automatic exchange of information which took place in 2013. It seems that the move can be traced to five European countries ${ }^{4}$ which declared their intent in 2012 to develop a system of mutual automatic exchange of information with the United States as a way of implementing the FATCA rules (Oberson, 2015). This marked an important development regarding the global standard of automatic exchange of information - a development that has been accelerated by the endorsement of the G20 leaders to the automatic exchange of information as the expected new standard. ${ }^{5}$ This global approach to exchange of information in tax matters has also transcended to regional organisations and their member countries.

Consequently, SADC has developed and implemented a framework for regional integration which commits member countries to a comprehensive programme of long-term economic and social policies ${ }^{6}$ (Saurombe, 2009). This framework is reflected in two important instruments: - "the Regional Indicative Strategic Development Plan (hereafter RISDP) and the Strategic Indicative Plan of the Organ (hereafter SIPO)" (www.sadc.int). Apart from that, SADC has adopted a Protocol on Finance and Investment and a Memorandum of Understanding on cooperation in Taxation and related matters which have been concluded with a view to advance tax cooperation within the member countries and with third-party countries.

\section{PRINCIPLES GOVERNING EXCHANGE OF INFORMATION}

The following principles underlie the exchange of information between tax administrators: - firstly, it is mandatory that "exchange of information must take place between the competent authorities identified in the instrument" (A practical guide on exchange of information for developing countries, 2013). This is the basic rule of exchanging information. This principle also finds its place in paragraph 1 of Article 26 of the OECD Model (www.oecd.org). Article 26 (1) of the OECD Multilateral Convention provides that, "the competent authorities of the Contracting States shall exchange such information as is foreseeably relevant for carrying out the provisions of this convention or for the administration or enforcement of the domestic laws concerning taxes of every kind and description imposed on behalf of the Contracting States, or of their political subdivisions or local authorities, in so far as the taxation thereunder is not contrary to the convention" (www.oecd.org).

Secondly, the exchange of information must relate to "persons and taxes as provided by the establishing legal instrument" (www.oecd.org). The exchange of information will be governed by an agreement between the tax authorities and will also specify the taxes which are covered by the exchange of information agreement. The agreement will also stipulate the persons who are covered by this legal instrument so as to give certainty to the types of taxes that fall within the ambit of the agreement.

\footnotetext{
${ }^{4}$ These countries are France, Germany, Italy, Spain and the United Kingdom -see www. web-xp2f-pws.ntrs.com [accessed on 17/09/2016]. ${ }^{5} \mathrm{G} 20$ refers to the Group of Twenty countries and a forum of the world's major advanced and emerging economies, (representing around 85 per cent of the global GDP).

${ }^{6}$ This programme was to begin with the establishment of a "Free Trade Area in 2008, followed by a Customs Union in 2010, a Common Market in 2015, and Monetary Union in 2016 and a single currency in 2018" as detailed out in SADC's plan of regional integration.
} 
Thirdly, "the information exchanged must be kept confidential and must be used only for the purposes provided for by the legal instrument" as provided by article 26 (1) (www.oecd.org). It is important for the principle of confidentiality to be strictly adhered to in regard to information which has been exchanged, in order for tax authorities to get support from taxpayers. The information which has been exchanged can only be used for purposes which have been clearly identified in the agreement and not for any other purpose which the tax authorities may identify after the signing of the agreement.

The significance of these principles is to ensure that the tax authorities of the States that have agreed to exchange information have guidelines which they have to act upon to govern their objectives and mandate. These principles are binding on both parties and are mandatory.

\section{INTERNATIONAL INSTRUMENTS}

The leading standard on exchange of information at the international level in the framework of double taxation conventions is based on the OECD model of double taxation conventions (DTC) (including the UN Model). The Multilateral Convention promotes international tax cooperation. At the international level, as provided for by the OECD, we have the Convention on Mutual Administrative Assistance in Tax Matters as amended by the 2010 Protocol which is the OECD and Council of Europe initiative (www.oecd.org; Pross and Russo, 2012; Seer, 2013). As alluded to by Sawyer 2015, the "Multilateral Convention was until 2010 only open to members of the OECD and of the Council of Europe". However, since June 2011, this position changed, as it became open to all countries. Therefore, this development made it possible for developing countries to benefit from the new approach which included cooperation of countries in tax matters as well as multilateral attitude towards the exchange of information amongst states (G20, 2009; Sawyer, 2015; OECD, Convention on Mutual Administrative Assistance in Tax Matters). Among SADC member countries, Seychelles (February 2015) and South Africa (November 2011) have signed the Multilateral Convention.

The amended Convention is intended to facilitate international collaboration to enhance an improved implementation of national tax laws, while regarding the basic human rights of taxpayers (www. oecd.org). The Convention represents a single multilateral instrument which lay down the basis of cooperation amongst member countries in order to achieve exchange of information in tax matters. The Convention is aimed at combating loss of revenues, including VAT revenues, caused by both legal and illegal tax minimization activities by, inter alia, exchanging tax information (Walpole, 2014).

The Multilateral Convention provides for the extent of its applicability and to which aspects it covers. The convention deals with all matters that underpin collaboration of countries on matters of exchange of tax information. As Sawyer 2015 indicates, the Convention also deals with "service of documents, joint audits, and assistance in collection of tax debts". It also requires members to guard taxpayer information from abuse as well as to uphold and respect the rights of taxpayers. The convention has a wide application as it covers all types of taxes except customs duties. In terms of article 2 (1)(a), the Convention covers "taxes on income, profits, capital gains, net wealth levied at the central government level" (www.oecd.org). It is therefore, significant in that, it can play an important part in matters of exchange of information particularly in the area of indirect taxes, specifically at a time when international VAT fraud is becoming a growing concern.

Article 26 of the OECD model convention represents the most relevant legal basis for the international exchange of information (Oberson, 2014). It provides the benchmark for international cooperation as far as exchange of information is concerned. 


\section{REGIONAL AGREEMENTS ON ASSISTANCE IN TAX MATTERS}

At the African regional level, the African Tax Administration Forum (hereafter ATAF)7 member countries have developed the Multilateral Agreement on Mutual Assistance in Tax Matters. The objective of this treaty is to assist member countries in tax matters. In terms of article 2 of ATAF Agreement, assistance here refers to, "the exchange of information in tax matters; the carrying out of tax examinations abroad; the carrying out of simultaneous examination; and assisting in tax collection" (Storbeck, 2013). Though this agreement is not yet in force, it signifies commitment of ATAF to the issue of exchange of information in tax matters, indicating that the issue is receiving attention among African countries.

At the sub-regional level, SADC has adopted the Protocol on Finance and Investment in 2006 (came into force in 2010) which lays the basis for coordination and cooperation in taxation issues. Annexure 3 of the Protocol reproduces the Memorandum of understanding on co-operation in taxation and related matters (which was adopted in 2002 to deal with issues of taxation in SADC). SADC has made progress in developing two important documents on exchange of information and tax treaties under these two instruments. Accordingly, the SADC tax subcommittee has through the tax agreements working group (TAWG), developed the following documents: - the SADC Model Tax Agreement for the Avoidance of double taxation (2009) and the SADC Agreement on Assistance in Tax Matters (2009, signed in 2012).

\section{SADC Model Tax Agreement for the Avoidance of Double Taxation}

This model tax agreement has been developed in terms of article 5 of the Protocol on Finance and Investment which provides for the establishment of "a common policy for State Parties for the negotiation of tax agreements amongst themselves or with other countries outside the region" (www.sadc.int).

Article 26 of this agreement deals with exchange of information between member countries and it follows the OECD approach and highlights the following key principles: - that information which is 'foreseeably' relevant for "administration or enforcement of domestic taxes of every kind and description is the type of information which is covered in this agreement" (www.sadc.int). The rule establishes that exchange of information can be done in different ways which are: - on request, spontaneously and automatically.

The member countries are expected to exchange information through the regular sources which are provided for before a request for information is made to the other member country. In cases where another member country has acquired information through the use of specific examinations or inquiries which it considers to be of importance to the other member country, the member country is expected to exchange such information with the latter country spontaneously. As far as the automatic exchange of information is concerned, a member country is expected to exchange information with another member country, for example, in cases where information about one of the various forms of income has its source in the first member country and is received in the latter member country, any information relating to that, must be communicated to the other member country automatically.

It is also provided that exchange of information must be treated with secrecy by member countries. This rule is critical in order to protect the rights of taxpayers whose information is being exchanged between the member countries. The SADC agreement is a model used by all SADC countries in negotiating double tax treaties amongst themselves and with other third-party countries outside the community. This is an approach equally adopted by the OECD.

\section{SADC Agreement on Assistance in Tax Matters}

This agreement is central to the notion of exchange of information in SADC and how this interrelates with deeper integration within the organisation. The Agreement on Assistance in Tax Matters (hereafter AATM) has been developed by the tax subcommittee in terms of article 5(5) of the Protocol on Finance and Investment which requires

${ }^{7} \mathrm{ATAF}$ is an international organisation which aims at promoting and facilitating cooperation among African Tax Administrations. ATAF consists of 36 member countries. Within SADC, the following thirteen countries are members of ATAF - Botswana, Lesotho, Madagascar, Mauritius, Malawi, Mozambique, Seychelles, Namibia, Swaziland, South Africa, Tanzania, Zambia and Zimbabwe. 
member states, through the subcommittee to develop strategies and procedures to achieve "effective exchange of information and implementation of Mutual Agreement Procedures" (www.sadc.int). The rationale behind the adoption of this Agreement is to ensure that issues relating to exchange of information and tax administration in general can be dealt with more speedily amongst member states as opposed to dealing with them through Double Taxation Treaties which usually focuses on tax policy issues. Adopted by SADC member states as a legally binding multilateral agreement, this Agreement has the objective of ensuring that member states assist each other in respect of tax matters, in particular those relating to: "exchange of information; carrying out of joint examinations; carrying out of simultaneous tax examinations; and assistance in the collection of taxes" (www.sadc.int).

\section{Key Features of the AATM}

Article 3 deals with those taxes which are within the scope of the agreement including: taxes on income and on capital; taxes on goods and services. This, however, excludes customs duties. ${ }^{8}$ Article 4 deals with exchange of information thereby following the OECD approach. It provides for different forms of exchange of information, which are spontaneous, automatic, or upon request. It specifically mentions that it deals with any such information 'as may be relevant' to a particular tax issue.

Article 5 of the agreement focuses on tax examinations abroad which are intended to enhance effective exchange of information and should occur in the territory of the requested State. It provides that these tax examinations abroad may take the following forms:

- Interview by officials of the requesting State, subject to a written consent of the taxpayer.

- Presence of officials of the requesting State during an examination by officials of the requested State may be present at any stage of the examination (No need for consent - only notification to the taxpayer - decisions on conduct of examination by officials of requested State).

- Simultaneous examinations - may be conducted through the initiation of one Contracting State for the States to discuss and decide collectively s for the purposes of determining cases as well as guidelines for simultaneous tax examinations.

- Under this arrangement, examinations take place in two or more States having a common interest in the affairs of a particular person/taxpayer.

- The purpose of examinations being to share information upon conclusion of such examinations.

Article 9 deals with the issue of costs. The parties agree to waive all claims for reimbursement of costs incurred in the execution of this agreement. In terms of this agreement, the parties agree that in the event that the requested party foresees that substantial expenses may be incurred in the provision of assistance pursuant to this agreement. Then, it would, before incurring such costs, notify the competent authorities of the requesting party and both parties through their relevant authorities shall agree on the modalities of how the cost shall be borne. This provision makes it easier for the parties to ensure that the burden of costs does not hinder the exchange of information which underlies the basis of this agreement. Therefore, the two involved states have to deal with the issue of how the costs will be covered even before the tax information can be exchanged between them. This provision however, falls short of providing that the costs which are incurred must be related to the benefits which are likely to flow from the exchange of information by the parties. This is a critical question which will form the basis of future research in this area. This provision also does not indicate where the budget to cover the costs will come from in each member state. It is critical for member states to determine clearly the budget that has been set aside to fulfil this mandate and which tier of state level is responsible for this responsibility, either the local level or the national level.

Article 10 mandates all member countries to pass legislation which is required to comply with the terms of this Agreement in order to enable them to provide the assistance in the Agreement. This provision is relevant for such SADC member states that may not already have such legislation in place.

${ }^{8}$ Custom duties are covered under a separate agreement between the member countries. 
Article 11 stipulates the relationship of this Agreement with other international agreements. It provides that this Agreement and other international agreements or arrangements should, in relation to cooperation in tax matters be seen to be complimentary of each other.

This agreement is intended to deal with challenges which are brought about by VAT carousel fraud schemes; VAT evasion schemes which are on the rise as a result of electronic commerce. The agreement therefore introduces the opportunity for tax authorities to share information in cases of such challenges which undermine the tax system. The agreement represents an important development in SADC on exchange of information for tax matters which is on the rise around the globe. SADC member countries are therefore obliged to uphold this principle and this contributes to mutual assistance and cooperation among them and third parties on tax issues. Tax issues and tax law were some of the issues which were neglected around the World, however, as a result of globalisation and the rise of foreign investment, as well as rising issues of tax avoidance, the issue of tax cooperation is at the centre of international investment and business.

\section{BILATERAL TAX INFORMATION ON EXCHANGE OF INFORMATION AGREEMENTS (TIEAS)}

Countries also have an opportunity to conclude bilateral tax information on exchange of information agreements (TIEAs) amongst themselves. As a result of the research by the "Global Forum on Transparency and Exchange of Information, of 2000" (Trepelkov, Tonino \& Halka 2015), the OECD issued in April 2002 a model "tax information exchange agreement (TIEA)" (www.oecd.org). According to Seer "this model agreement involves the exchange of fiscal information between OECD member countries and tax havens identified by the OECD and represents a result of the initiative "Harmful Taxation Project" (Seer, 2013). This OECD TIEA represents the OECD standard for an effective information exchange in terms of paragraph 5.5 of the agreement. The model agreement is not a binding agreement (Seer, 2013). This model agreement forms the basis for the majority of bilateral mutual administrative and legal agreements around the world (Seer, 2013). This can be in the form of TIEA's. Different jurisdictions can choose to use the wording of the articles of the model agreement on TIEA in order to develop agreements with other countries to conclude new TIEA. Information which is shared under TIEA's can only be exchanged on request and may not be shared with third parties. The requesting state must confirm that it has pursued all available means to obtain the information in its own jurisdiction. The tax authorities of one state may only carry out tax examinations in the other state or be present at tax examinations abroad with written consent of the persons concerned (Walpole, 2014).

This agreement has since been used as a model for negotiating TIEAs by countries. The significance of TIEAs is that, they can be used even in cases where double tax treaties do not exist. Since our focus in this paper is the position in the SADC region, we, therefore, highlight two of the relevant bilateral agreements on exchange of information in the region.

Agreements between South Africa and Lesotho; and South Africa and Swaziland on mutual assistance and cooperation and the prevention of fiscal evasion with respect to value-added tax (Government notice no.270/2015, www.sars.gov.za)

The two agreements which have been concluded between South Africa and Lesotho; and South Africa and Swaziland are examples of bilateral tax information agreements (TIEAs) which are discussed in the paragraph above. The present discussion focuses on the design and the contents of these legal instruments. A future line of research to evaluate the costs and benefits of these agreements will be considered in order to determine the effectiveness of the legal instruments.

These two agreements contain similar provisions and objectives hence they are discussed within that context. Though these agreements focus on cooperation and mutual assistance specifically for VAT, it is argued that similar cooperation efforts can be extended to other forms of taxes.

These two agreements focus on the following four aspects: - (1) "to establish a refund system to administer the refund and assessment of tax as provided for by the agreement" (www.sars.gov.za) - a Memorandum of Understanding is to be developed to expand on this aspect; (2) Refund procedures; (3) Exchange of information; and (4) Authenticity of tax invoices. This discussion focuses mainly on article 4 which deals with the aspect of exchange of information, the 
main theme of this paper. Article 4(1) states that, "the tax authorities of the contracting States shall exchange any information which is foreseeably relevant for the correct assessment or refund of tax or to combat the evasion or avoidance of tax. Exchanges will be done in accordance with the existing Agreement for the Avoidance of Double Taxation and the Prevention of Fiscal Evasion between the contracting States" (www.sars.gov.za). These agreements contain this broad provision with regard to exchange of information and leaves it to the member states on how the implementation of this provision is effected. However, it is clear that the existing Double taxation agreements between the states are critical to the exchange of information for tax purposes. Since these agreements focus mainly on cooperation with respect to VAT, it is clear that the exchange of information in article 4 relates to VAT and not to any other type of tax.

\section{FORMS OF EXCHANGE OF INFORMATION}

In terms of Article 26 (1) of the OECD multilateral Convention, "information can be exchanged in three different ways; on request; spontaneously or automatically" (www.oecd.org). These forms of exchange of information have also been included in the SADC agreements. The exchange of information upon request means that the requesting State would demand from the other Contracting State information foreseeably relevant in a specific situation. This means that any tax information which the requesting state thinks will likely be relevant to a specific situation of a tax nature, it is permitted to request such information.

The other form of exchange of information can be 'spontaneous'. According to a Practical guide on exchange of information, "this is the provision of information to another State that is foreseeably relevant to that party but has not been previously requested" (A Practical Guide on Exchange of Information for Developing Countries, African Tax Administration Forum, 2013). In this case, information which is being requested was not necessarily planned or agreed to by the state parties, it is being requested by the other party on as and when it is found to be required. There can also be automatic exchange of information. This refers to where the state parties realise upon instinct that the tax information which they have can be relevant to the other party and voluntarily shares the information. This form of exchange of information is based on 'instinct' of the state parties. Apart from the foregoing three methods, the other forms of exchange of information can be through the tax examination board; simultaneous examination; information can also be exchanged through joint audits.

The OECD has developed a Manual on the Implementation of Exchange of Information Provisions for Tax Purposes in 2006 (www.oecd.org). The Manual provides an overview of the operation of the exchange of information principles. In its paragraph 2, the Manual also describes the various forms of exchange of information as developed by article 26 (1) of the OECD convention.

\section{LIMITS TO THE EXCHANGE OF INFORMATION}

There are limitations to the principle of exchange of information amongst tax authorities which dictate how this principle should be balanced with the principle of state sovereignty in international law. Firstly, the requesting State is expected to observe the principle of subsidiarity. The principle of subsidiarity provides that the requesting State must first use a regular source of information available under its domestic law before sending a request to the other State. In terms of this principle, the exchange of information under article 26 is secondary to the domestic information gathering process.

Secondly, the requesting State has to take into account the existing domestic limits in the State from which information is requested, therefore, this must be respected by the requesting State. The requesting State must observe the principle of reciprocity which demands that the State will reciprocate the exchange of information if the other State requests information. The principle of reciprocity ensures that the requesting State will lend the same favour to exchange information to the other State in future if such a request is made. This principle guarantees that the two states benefits equally from the obligations arising from the legal instruments.

Thirdly, the principle of exchange of information is also limited by issues of trade or business secrecy which might exist in regard to the information which is being requested. In cases where some of the information is protected under trade agreements, the states involved cannot exchange such information with another state. This will be in accordance 
with the trade secrecy clauses under the trade agreement. Fourthly, the issue of public policy will also limit how the principle of exchange of information is applied. Public policy dictates various developments which affect how various policies are developed within a country. In this case, where public policy dictates against exchange of information or certain conditions are imposed due to public policy, therefore, this principle will be applied with such limitations.

\section{CHALLENGES OF EXCHANGE OF INFORMATION FOR SADC (AND OTHER AFRICAN) COUNTRIES}

Despite the developments in the SADC region on exchange of tax information, there is still a long way to go for the effective implementation of the existing instruments and achieving effectiveness of the principle. There are still challenges which exist for effective exchange of information to be achieved in SADC and in the African continent as a whole. Firstly, as indicated by Storbeck 2013, it seems that "lack of treaties as instruments for exchange of information in several African countries" inhibits the implementation of the principle. Though in the SADC region South Africa, Swaziland and Lesotho have taken steps towards concluding agreements to this effect, this is not widespread among the member countries. There is still reluctance in SADC countries and African countries to negotiate agreements to regulate exchange of information. It could be argued that the reluctance in SADC countries is a result of negotiating a lot of legal instruments without testing their effectiveness and implementation. SADC has negotiated and signed a lot of legal instruments and in some cases, the implementation of such instruments has not been achieved by member countries. In some cases, there are cost implications to implement the legal instruments and this has also contributed to the reluctance by member countries to negotiate any further agreements. The cost-benefit analysis to implement the exchange of tax instruments is a possible future line of research which will be explored.

Secondly, lack of adequate legislation and other forms of regulatory framework to guarantee access of information for exchange purposes is one of the challenges facing SADC as well as other African countries (Storbeck, 2013). The governments of these countries do not regard the adoption of the regulatory framework in exchange of tax matters as a priority within their societies, therefore, they tend to focus on other types of economic matters within their countries. Thirdly, lack of technical capacity in some tax administrations to handle requests for exchange of information frustrates the proper implementation of the relevant agreements (Storbeck, 2013). In most of the SADC (as well as other African) countries, tax administration offices are under staffed and lack sufficient trained staff in either taxation or tax law. As a result the tax administrations tend to focus more on collection of taxes rather than on related issues. And lastly, the lack of political will from the member countries which in most cases is caused by lack of resources towards the effective implementation of these instruments.

\section{RECOMMENDATIONS AND CONCLUSION}

According to the OECD, "exchange of information is the most effective tool to combat cross border tax fraud" (www.oecd.org). The OECD comes to this conclusion on the basis of a number of observations. There are currently over 100 jurisdictions which have committed to exchanging information with each other under the Common Reporting Standards (hereafter CRS) ${ }^{9}$ (www.oecd.org). The OECD has developed a global standard on Automatic Exchange of Information (AEOI) which provides for the exchange of financial account information of non-residents with the tax authorities in the country of residence of the account holder (www.oecd.org). This has also gained support from the G20 countries. With this new standard, participating countries financial institutions in those countries are required to report the information of the non-residents to tax authorities in the country of residence on an annual basis. The OECD is of the view that this standard will minimise costs to concerned governments and business when it is implemented in September 2017 due to the fact that, the requirements have been consolidated in one standard and the reporting mechanism is done on an annual basis in terms of CRS. However, developing countries have generally only made a limited use of information exchange because they were lacking the legal basis for exchange. This was a result of awareness of tax administrations of the role of exchange of information in identifying possibilities of tax evasion and avoidance. Furthermore, according to the OECD this was also a result of "the lack of knowledge about the implementation of exchange of information as well as capacity constraints" (www.oecd.org).

The establishment of the Global Forum on Transparency and Exchange of Information for Tax Purposes (hereafter the Global Forum) has also contributed to the effectiveness of the exchange of information as a tool as it oversees the

${ }^{9}$ The CRS are based on the Multilateral Convention. 
implementation and tax compliance with the adopted standards of transparency and exchange of information in tax matters (www.oecd.org). The Global Forum has currently 139 members. A further study examining the cost-benefit analysis of these multilateral instruments in both the OECD countries and other developing countries will be part of future research.

An international institutional framework is starting to emerge to facilitate the exchange of tax related information and promote tax information transparency more generally. This has been driven by the OECD. In 2013, a new move towards automatic exchange of information evolved which was supported initially among states in the European Union and among other international organizations such as the OECD and the UN.

The latest developments and initiatives in the United States of the adoption of FATCA in 2010 and the suggested alternative model of withholding tax, the so-called 'Rubik' Model, in Switzerland are some of the notable developments in this area of the law (Trepelkov, Tonino and Halka 2015). ${ }^{10}$

In the context of SADC, member countries have adopted a large variety of measures that are aimed at combating tax fraud and encouraging greater cooperation amongst tax authorities. These measures are in the form of adopting the relevant agreements which facilitate the exchange of information on tax issues amongst member countries. There is no doubt that these agreements are also intended to deepen regional integration amongst member countries. In cases where member countries achieve greater cooperation, that strengthens regional integration within the region in all trade issues. These agreements are important steps to improve exchange of tax information and tax enforcement within SADC, however the effectiveness of these instruments will be closely watched.

As a measure to improve the cooperation of the tax authorities, SADC should focus on training the tax administrators to address lack of technical capacity. Furthermore, South Africa should take the leading role in providing training and assistance to both SADC officials and member countries in addressing some of the challenges. The member countries of SADC should also look at the OECD practices and how the Multilateral Convention is being implemented. Furthermore, to achieve the goal of a coordinated approach in exchange of information by SADC member countries, as it is suggested by Seer to the EU Member States in regard to the Directives 2010/24/EU and 2011/16/EU towards improving tax enforcement within the EU, which can also be suggested to SADC member countries, "they have to invest in staff, education and technology to implement mutual assistance in tax administration reality" (Seer, 2013). It is acknowledged that the issue of costs towards financing the training of staff and improving technical resources towards tax administration is a major setback and limitation to this study, hence this will be part of future research which will investigate the effectiveness of the legal instruments in exchange of information as methods to improve 'exchange of information in tax matters'. Furthermore, the absence of an evaluation of the exchange of tax information in tax matters and statistically supported analysis of improvements in SADC and elsewhere due to improved tax administration is another limitation to this study and these limitations can be topics for future research in this area.

\footnotetext{
${ }^{10}$ These two models are not discussed in this paper as they are not directly relevant to the developments which are taking place in SADC. See the United Nations Handbook on Selected Issues in Protecting the Tax Base of Developing Countries, 2015. See L.U. Cavelti, "Automatic Information Exchange versus the Withholding Tax Regime Globalization and Increasing Sovereignty Conflicts in International Taxation", World Tax Journal (2013) p180 - p200 and X. Oberson, International Exchange of Information in Tax Matters (2015) p.173-176 for detailed discussions of these two models.
} 
Figure 1. Map of SADC countries (highlighted in grey)

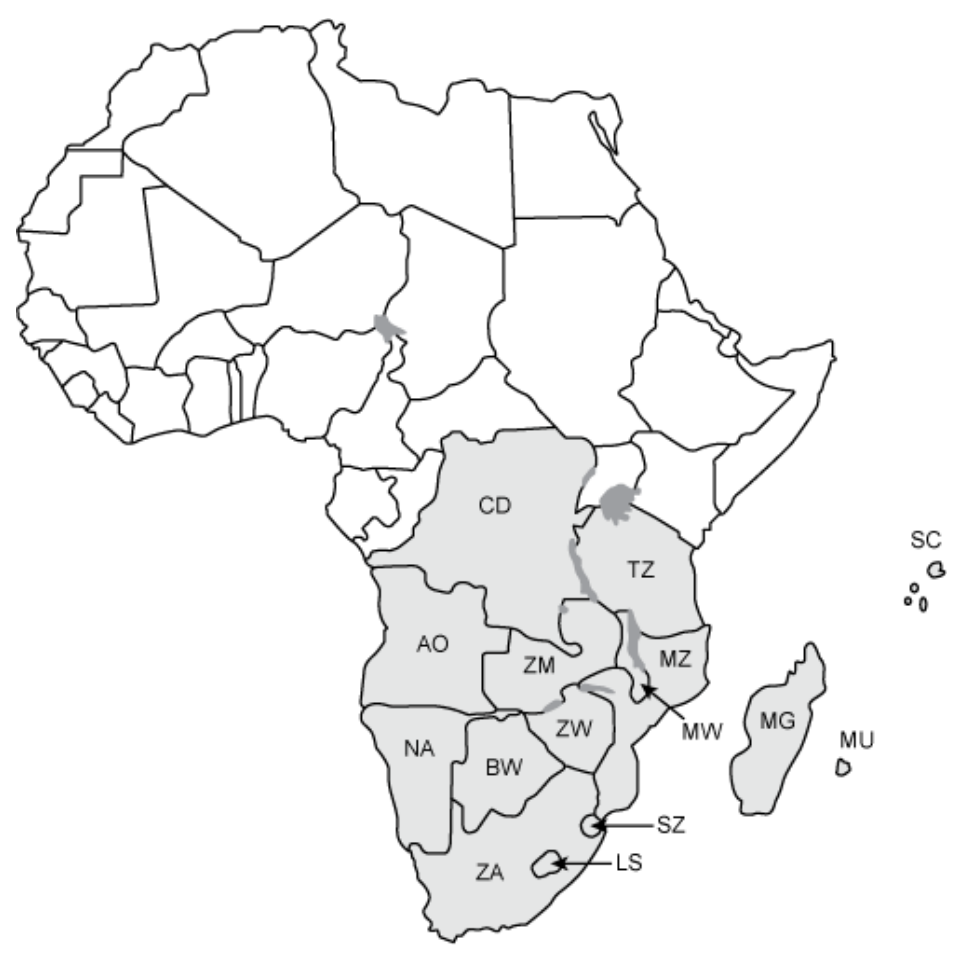

ACKNOWLEDGEMENT

I acknowledge the generous funding support from the National Research Fund (NRF) through the Knowledge Interchange and Collaboration Grant for 2014/ 2015.

\section{AUTHOR BIOGRAPHY}

Puseletso Letete, is an Associate Professor in Tax Law at the University of South Africa (UNISA) where she lectures tax law at both undergraduate and postgraduate level and supervises postgraduate students. She holds a doctoral degree (Tax Law) from the University of Edinburgh; a Masters in Commercial Law from the University of Cape Town; and a Bachelor of Laws degree from the National University of Lesotho. Prior to joining the University of South Africa, she lectured tax law and public international law at the National University of Lesotho. She has researched and published on VAT law and taxation of cross-border transactions in Southern African Development Community (SADC) and Southern African Customs Union (SACU) as well as in tax administration issues. She regularly speaks on tax issues at international and domestic conferences. She is registered as a Master practitioner by the South African Institute of Tax Practitioners (SAIT).

\section{REFERENCES}

A practical guide on exchange of information for developing countries. (2013). The African Tax Administration Forum. www.oecd.org [accessed on 17/09/2016].

Agreement between the Government of South Africa and the Government of Lesotho on mutual assistance and co-operation and the prevention of fiscal evasion with respect to value-added tax. (May 2015). Government Notice, South African Revenue Service, No.365.

Agreement between the Government of South Africa and the Government of Swaziland on mutual assistance and co-operation and the prevention of fiscal evasion with respect to value-added tax. (March 2015). Government Notice, South African Revenue Service, No.270.

Cavelti, L. U. (2013). Automatic information exchange versus the withholding tax regime globalization and increasing 
sovereignty conflicts in international taxation. World Tax Journal, 172-214.

Convention on mutual administrative assistance in tax matters. (2010). Available at www.oecd.org. [accessed on 9 May 2016 ]. Foreign Account Taxpayer Tax Compliance Act. (2010). United States of America.

G20 London Summit. (April 2009). Communique. Available at www.oecd.org. [Accessed on 9 August 2016]. Hartzenberg. (2011). Regional integration in Africa. World Trade Organization Economic Research and Statistics Division: Staff working Paper ERSD-2011-14 October, 2.

Letete, P. (2012). Between tax competition and tax harmonisation: Coordination of value added taxes in SADC member states. Law Democracy \& Development, 16, 119-138 www.saflii.austlii.edu.au [accessed on 27/08/2016].

Oberson, X. (2015). International Exchange of Information in Tax Matters Towards Global Transparency. Edward Elgar

Publishing: Cheltenham, United Kingdom.

OECD Global forum on transparency and exchange of information for tax purposes. (2000). Available at http://www.oecd.org/document/33/0,3746,en21571361_43854757_44200609_1_1_1_1,00.html. [Accessed on 9 August 2016].

OECD Manual on the implementation of exchange of information provisions for tax purposes. (2006). Available at http://www.oecd.org/tax/exchange-of-tax-information/36647823.pdf [Accessed on 12 August 2016], Paragraph 2.

Pross A., \& Russo, R. (2012). The amended convention on mutual administrative assistance in tax matters: A powerful tool to counter tax avoidance and evasion. Bulletin for International Taxation, 68, 361-365.SADC Agreement on assistance in tax matters. (2009, signed in 2012).

SADC Model tax agreement for the avoidance of double taxation. (2009).

SADC's Regional indicative strategic development plan. (2003).

Saurombe, A. (2009). Regional integration for SADC caught in the winds of change: Problems and prospects. Journal of International Commercial Law and Technology, 4, 100-106.

Sawyer, A. (2014). Comparing the Swiss and United Kingdom cooperation agreements with their respective agreements under the Foreign Account Tax Compliance Act. eJournal of Tax Research, 12, 285-318.

Sawyer, A. (2015). The implications of the Multilateral Convention and the Foreign Account Tax Compliance Act: An Australasian perspective. AT Rev, 44, 1-21.

Seer, R. (2013). Recent developments in exchange of information within the EU for tax matters. EC Tax Review, 2 , 66-77.

Storbeck, E. (2013). Capacity Building on Tax Treaty Administration. The African Tax Administration Forum (ATAF). Presentation at the Joint Meeting by FfDo of UNDESA and the ITC. (Rome: Italy).

Treaty of the Southern African Development Community (SADC). (1992).

Trepelkov A., Tonino H., \& Halka D. (2015) ed. United Nations Handbook on Selected Issues in Protecting the Tax Base of Developing Countries. United Nations: New York. Available at www.un.org [accessed on 24/09/2016].

Walpole, M. (2014). Tackling VAT Fraud. International VAT Monitor, September/October, 258 - 263. 